\title{
PRIMJENA METODA ODLUČIVANJA U LOKALNOJ SAMOUPRAVI
}

\author{
Valentina Đurek \\ Dipl. inf. univ. spec. oec., Grad Zabok, Zivtov trg 10, 49210 Zabok, Hrvatska; e-mail: valentina@zabok.hr
}

\section{Claudia Sedda}

Mag. iur., Eurobridge, Via Roma 250, Gavoi 08020, Italija; e-mail: info@eubridge.eu

\begin{abstract}
SAŽETAK
Suradnja s udrugama u provedbi javnih politika najčešće se očituje kroz različite oblike financijske i nefinancijske podrške koje jedinice lokalne samouprave pružaju programima i projektima od interesa za opće dobro. Ta vrsta međusektorske suradnje ima veliki potencijal za generiranje brojnih pozitivnih promjena i stvaranje prijeko potrebnih sinergija za održiv društveni i gospodarski razvoj. U kojoj će mjeri taj potencijal biti ostvaren, uvelike ovisi o kvaliteti kriterija, standarda i postupaka za dodjelu financijskih i nefinancijskih podrški, kao i organizacijskim i ljudskim resursima unutar javnih institucija nužnih za uspješno praćenje i vrednovanje ugovorenih modela podrške. Glavni cilj ovog rada je na primjeru pokazati kako je moguće unaprijediti kvalitetu donošenja odluka u lokalnoj samoupravi primjenom metoda odlučivanja u procesu donošenja odluka o financiranju udruga u kulturi. Na primjeru će se odrediti važnost (težinski koeficijenti) kriterija i podkriterija za procjenu kvalitete projekata/prijava udruga u kulturi ( $N=18)$ s područja Grada Zaboka. Isto tako, u ovom radu AHP metoda primijenit će se za izradu modela rangiranja programa/projekata u kulturi koji su financirani iz proračuna Grada Zaboka. Model će se validirati na povijesnim podacima iz 2018. godine.
\end{abstract}

Ključne riječi: višekriterijsko odlučivanje, AHP, matrica rizika, udruge, kultura

\section{UVOD}

Jedinice lokalne samouprave planiraju sredstva u proračunu, odnosno financijskom planu za narednu kalendarsku godinu za sufinanciranje programa/projekta udruga koja se raspodjeljuju temeljem Javnog natječaja. Iznos koji će se dodjeljivati udrugama od 2016. godine ne planira se u proračunu davatelja temeljem iznosa koji predlažu same udruge na osnovi vlastitih potreba za financijskim sredstvima, već se okvirni iznos za financiranje planira temeljem procjene prioritetnih potreba. Osim iznosa financijskih sredstava koja će se putem natječaja dodjeljivati udrugama, planiranje financijskih resursa za provedbu natječajnog procesa uključuje i planiranje dodatnih sredstava za troškove rada povjerenstva, za potencijalna stručna usavršavanja, za moguće troškove 
povezane s najmom dvorana za predstavljanje ugovorenih projekata, odnosno programa ako davatelj financijskih sredstava već ne raspolaže dovoljnim prostorima, za podugovaranje provedbe svih ili pojedinih elemenata postupka financiranja i dr.

Praćenje rada udruga u kvalitativnom i financijskom smislu Grad Zabok je do 2015. godine provodio u skladu s mogućnostima Proračuna temeljem iznosa koji su predlagale same udruge. Prema Službenom glasniku Krapinsko-zagorske županije (2015) sufinanciranje za 2016., 2017.i 2018. godinu provedeno je sukladno odredbama Pravilnika o financiranju i odobravanju nefinancijskih podrška udrugama, te odredbama Uredbe o kriterijima, mjerilima i postupcima financiranja i ugovaranja programa i projekata od interesa za opće dobro koje provode udruge (Narodne novine, 2015). U ovom radu predlažu se metode za dodjelu sredstava udrugama temeljem Javnog natječaja čiji su obveznici sve JLS u Republici Hrvatskog (temeljem gore spomenute Uredbe), a primjena metode bit će demonstrirana na primjeru Grada Zaboka i dodijele sredstava udrugama u kulturi.

Sukladno navedenom, Grad Zabok pripremio je novi Javni natječaj za financiranje rada udruga s područja Grada Zaboka u 2019. godini kojim se definiraju glavna područja intervencije Grada Zaboka u kojima će se pružiti odgovarajuća financijska i institucionalna potpora za rad udruga s područja Grada Zaboka. Javni natječaj predstavlja temelj za izradu učinkovitog sustava financiranja programa i projekata organizacija civilnog društva s područja Grada Zaboka. Provođenje Javnog natječaja temelji se na načelima:

1.Transparentnosti - svaka udruga prilagala je zahtjev za financiranje uz opise akcija koje se planiraju provoditi te je javnost bila obaviještena o načinu i svrsi financiranja udruga koje su ostvarile potporu iz gradskog proračuna;

2. Jednakih mogućnosti - svaka udruga je putem javnog natječaja imala jednaku mogućnost ostvariti potporu iz proračuna;

3. Usmjerenosti - sredstva su dodjeljivana udrugama koje su jasno opisale doprinos projekta ostvarenju javnog interesa i općeg dobra svih građana grada Zaboka.

Prilikom pripreme Javnog natječaja i natječajne dokumentacije, gradske službe pridržavale su se Kodeksa pozitivne prakse, standarda i mjerila za ostvarivanje financijske potpore projektima i programima udruga. Tijekom 2018. godine ukupno je 27 udruga ostvarilo potporu Javnog natječaja za financiranje programa ili projekata udruga koji doprinose razvoju kapaciteta udruga iz prioritetnih područja kulture (18 udruga) i socijalne skrbi ( 9 udruga).

\section{PREGLED DOSADAŠNJE LITERATURE}

Rezultati pregleda dosadašnje literature pokazali su da su primjeri korištenja metoda višekriterijskog odlučivanja u jedinicama lokalne samouprave (JLS) i regionalne samouprave rijetki te da su u različitim područjima primjene.

Autori Magbagbeola et al. (2012) u svojem radu prikazuju primjenu metode za višekriterijsko odlučivanje AHP (engl. Analytical Hierarchy Process) u rješavanju problema statističkih podataka 
u poljoprivredi na razini jedinice lokalne samouprave, dok autori Tot et al. (2016) u svojem radu analiziraju, primjenom metode AHP, koji ključni čimbenici utječu na razvoj održivog gospodarenja otpadom.

Autori Setiawan et al., (2016) navode da se primjenjuje koncept sustava podrške grupnom odlučivanju za procjenu učinkovitosti projekata IKT-a u indonezijskim regionalnim državnim agencijama kako bi se prevladale sve moguće nedosljednosti do kojih može doći prilikom donošenja odluka pri čemu se integriraju metode AHP, TOPSIS (engl. Technique for Order Preference by Similarity to Ideal Solution) i metode Copeland za određivanje najbolje rangiranih projekta od strane donositelja odluka.

Autori Kadoic et al. (2016) u svojem radu prikazuju primjenu dviju metoda za višekriterijsko odlučivanje koje su podržane IKT-om: metoda AHP i rangiranje na temelju ocjena sudionika kao novi pristup za rješavanje problema u JLS-u, budući da u Republici Hrvatskoj nema primjera koji podržavaju IKT donošenje odluka u malim gradovima ili općinama.

UtjecajIKT-a u strukturnom dijalogu između donositelja odluka nalokalnoj, regionalnoj, nacionalnoj i europskoj razini i građana, te metodologija koja će pomoći povećati razinu strukturiranog dijaloga između JLS-ova i nevladinih organizacija primijenjena je u projektu „Go, go, NO!“ (Kadoić, 2016). $U$ jedinicama lokalne samouprave može se povećati razina strukturiranog dijaloga u područjima različitih društvenih pitanja korištenjem metodologije koja se temelji na Demingovom krugu i Sustavu uravnoteženih ciljeva (engl. Balanced Scorecard - BSC) (Kadoić, 2017).

Autori Listyaningsih i Utami (2018) navode da su se metode višekriterijskog odlučivanja AHP i TOPSIS pokazale vrlo učinkovitima u evaluaciji učinkovitosti jedinica lokalne samouprave; AHP metoda koristila se za određivanje težinskih vrijednosti kriterija, a TOPSIS metoda za rangiranje učinkovitosti JLS-ova.

\section{MODELIRANJE SUSTAVA ODLUČIVANJA ZA ODABIR PROGRAMA/ PROJEKATA AHP METODOM}

Odlučivanje je kognitivni proces koji se sastoji od prepoznavanja problema i biranja mogućih rješenja koja vode do nekog željenog stanja. Odlučivanje je vrlo odgovoran i težak posao jer donošenje odluka za sobom nosi i način provođenja inih. Odlučivanje je prisutno u svakodnevnom životu, u profesionalnom i privatnom. Sposobnost donošenja odluke je vještina koja se usavršava s vremenom i iskustvom. Prema Weihrichu i Koontzu (1998), odlučivanje je izbor načina djelovanja između više alternativa. Prema Daftu (2001), proces odlučivanja je proces identifikacije i proces rješavanja problema.

U privatnom odlučivanju u velikoj se mjeri koristi intuitivno odlučivanje. Prema autorima Sikavica et al. (1999) poslovno odlučivanje zahtijeva više sistematičnosti nego odlučivanje u privatnom životu, zato što pogađa veći broj članova organizacije. Što je razina odlučivanja viša s aspekta raspona odgovornosti, to je i odlučivanje važnije budući da se tiče velikog broja članova organizacije pa u slučaju pogrešne odluke može imati katastrofalne posljedice za organizaciju kao cjelinu. 


\section{1 Višekriterijsko odlučivanje}

Višekriterijsko odlučivanje primjenjuje se u situacijama odlučivanja kada postoji veći broj konfliktnih kriterija. Karakteristike problema višekriterijskog odlučivanja su prisutnost većeg broja kriterija ili atributa, konflikt među tim kriterijima, neusporedivost mjernih jedinica između kriterija, prisutnost većeg broja alternativa koje se međusobno razlikuju po vrijednostima određenih kriterija te izbor alternative koja je ukupno gledano između svih alternativa najbolja. Glavni elementi problema odlučivanja su ciljevi koji se žele postići odlukom, alternative između kojih se bira, kriteriji kojima se mjeri postizanje ciljeva i težine tih kriterija koje odražavaju njihovu važnost s obzirom na problem. Problem višekriterijskog odlučivanja moguće je prikazati pomoću tablice odlučivanja ili matrice koja je tipa gdje se u redovima nalazi alternativa ili mogućnosti, a u stupcima kriteriji ili atributi. Polje matrice predstavlja vrijednost atributa alternative. Redak matrice predstavlja vrijednosti atributa jedne alternative dok jedan stupac predstavlja vrijednosti jednog atributa za alternative koje su predmet odlučivanja.

\subsection{Analitički hijerarhijski proces - AHP metoda}

Analitički hijerarhijski proces - AHP metoda jedna je od najpoznatijih metoda višekriterijskog odlučivanja. Prvi puta metodu spominje autor Saaty (1972). Autor Saaty (1977) detaljno opisuje metodu AHP. Mnogi autori u svojim radovima najčešće se referenciraju na knjigu istog autora objavljenu 1980. godine u kojoj autor Saaty (1980) navodi da se primjena AHP metode sastoji od 4 glavna koraka:

1. Razviti hijerarhijski model problema odlučivanja s ciljem na vrhu, kriterijima i podkriterijima na nižim razinama te alternativama na dnu modela (Slika 1). Potrebno je prepoznati cilj koji se želi postići, definirati alternative koje zadovoljavaju postavljene zahtjeve, definirati prioritete zahtjeva kako bi se alternative implementirale i ostvario globalni cilj. Složenost problema raste s brojem kriterija i s brojem alternativa. Sposobnost ljudskog uma u međusobnom razlikovanju velikog broja alternativa i kriterija je ograničena, te se u skladu s time, pri formiranju hijerarhije ne preporučuje više od elemenata na istoj razini. 
Slika 1. Hijerarhijski model problema odlučivanja

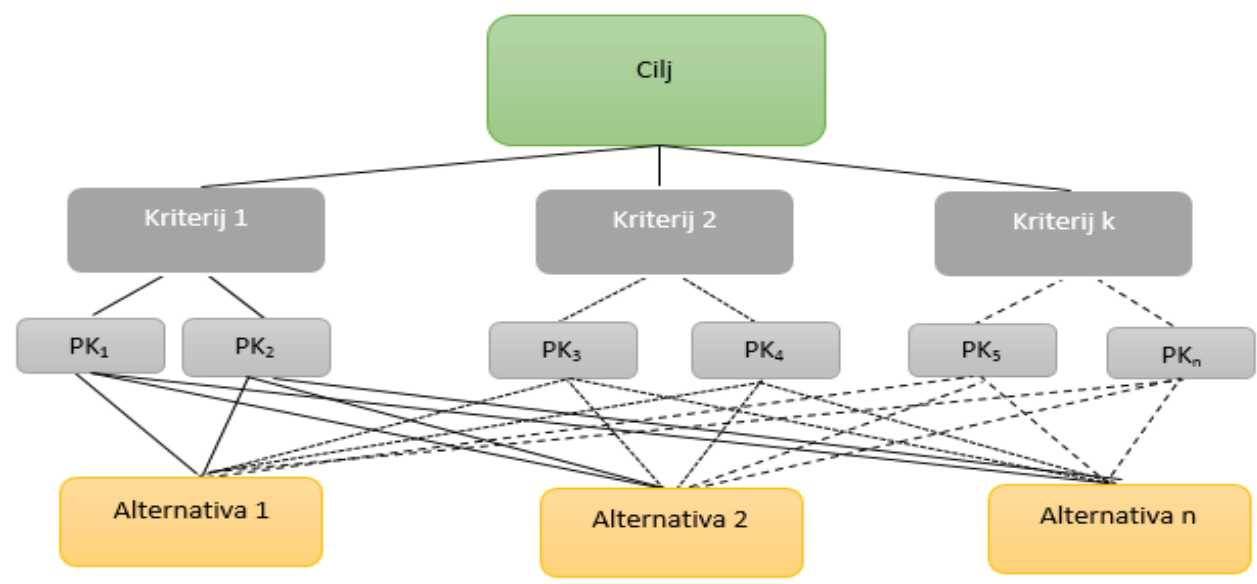

Izvor: obrada autora

2. U svakom čvoru hijerarhijske strukture međusobno se uspoređuju u parovima elementi tog čvora u odnosu na to koliko je puta jedan od njih važniji od drugog za postizanje cilja pomoću Saatyjeve ljestvice ocjenjivanja (Tablica 1).

Tablica 1. Saatyjeva ljestvica relativnih važnosti

\begin{tabular}{|c|c|c|}
\hline $\begin{array}{l}\text { Intenzitet } \\
\text { važnosti }\end{array}$ & Definicija & Objašnjenje \\
\hline 1 & Jednako važno & Dvije aktivnosti jednako doprinose cilju. \\
\hline 2 & $\begin{array}{l}\text { Slabo, blago važnije } \\
\text { Umjereno važnije }\end{array}$ & $\begin{array}{l}\text { Na temelju iskustva i procjena daje se umjerena prednost } \\
\text { jednoj aktivnosti u odnosu na drugu. }\end{array}$ \\
\hline $\begin{array}{l}4 \\
5\end{array}$ & $\begin{array}{l}\text { Umjerenije do } \\
\text { Strogo važnije }\end{array}$ & $\begin{array}{l}\text { Na temelju iskustva i procjena, strogo se favorizira jedna } \\
\text { aktivnost u odnosu na drugu. }\end{array}$ \\
\hline $\begin{array}{l}6 \\
7 \\
\end{array}$ & $\begin{array}{c}\text { Važna do } \\
\text { Vrlo stroga, dokazana važnost } \\
\end{array}$ & $\begin{array}{l}\text { Jedna aktivnost izrazito se favorizira u odnosu na drugu, } \\
\text { njezina dominacija dokazuje se u praksi. }\end{array}$ \\
\hline $\begin{array}{l}8 \\
9\end{array}$ & $\begin{array}{l}\text { Vrlo, vrlo stroga do } \\
\text { Ekstremna važnost }\end{array}$ & $\begin{array}{l}\text { Dokazi na temelju kojih se favorizira jedna aktivnost u } \\
\text { odnosu na drugu, potvrđeni su s najvećom uvjerljivošću. }\end{array}$ \\
\hline $2,4,6,8$ & Međuvrijednosti & \\
\hline $1.1-1.9$ & Slične aktivnosti & $\begin{array}{l}\text { Pri usporedbi aktivnosti koje su po važnosti blizu jedna } \\
\text { drugoj, potrebne su decimalne vrijednosti kako bi se } \\
\text { preciznije izrazila razlika u njihovoj važnosti. }\end{array}$ \\
\hline
\end{tabular}

Izvor: T. L. Saaty (1977) 
3. Iz procjena relativnih važnosti elemenata odgovarajuće razine hijerarhijske strukture problema izračunaju se lokalne težine (prioriteti) kriterija i podkriterija, a na posljednjoj razini prioriteti alternativa. Ukupni prioriteti alternativa izračunavaju se tako da se njihovi lokalni prioriteti ponderiraju s težinama svih čvorova kojima pripadaju gledajući od najniže razine u hijerarhijskome modelu prema najvišoj i zatim zbroje.

4. Provodi se analiza osjetljivosti.

Prema Harkeru i Vargasu (1987) i Begičević (2008) AHP metoda zasniva se na sljedećim aksiomima:

1. Aksiom recipročnosti. Ako je element $A$ puta značajniji od elementa $B$, tada je element $B$ puta značajniji od elementa $A$.

2. Aksiom homogenosti. Usporedba ima smisla jedino ako su elementi usporedivi.

3. Aksiom zavisnosti. Dopušta se usporedba elemenata jedne razine u odnosu na element više razine, tj. usporedbe na nižim razinama zavise od elementa više razine.

4. Aksiom očekivanja. Svaka promjena u strukturi hijerarhije zahtijeva ponovni postupak računanja prioriteta.

\section{3 Razvoj AHP modela}

AHP model za rangiranje programa/projekata u kulturi izrađen je u četiri koraka: Određivanje kriterija i podkriterija, Procjena važnosti kriterija u parovima, Matrica procijenjenih omjera važnosti kriterija i podkriterija te Izračun težinskih koeficijenata kriterija i podkriterija.

\subsection{Određivanje kriterija i podkriterija}

U cilju osiguravanja odgovarajuće financijske i institucionalne potpore za rad udruga Grad Zabok raspisuje Javni natječaj za financiranje potpore programima i projektima udruga kojim se utvrđuje koje će udruge u proračunskoj godini biti sufinancirane za prijavljene programe/projekte i u kojim iznosima. Odluka o odabiru financiranja programa/projekata udruga donosi se na temelju kriterija. Kriteriji su određeni temeljem Uredbe o kriterijima, mjerilima i postupcima financiranja i ugovaranja programa i projekata od interesa za opće dobro koje provode udruge (Narodne novine 26/2015.), međutim davatelj financijskih sredstava može uvjetima natječaja propisati da udruga mora ispunjavati i dodatne uvjete. Kriteriji relevantni za odabir programa/projekata u kulturi koje sufinancira Grad Zabok podijeljeni su u četiri skupine (Slika 2):

- Institucionalna sposobnost prijavitelja/partnera

- Relevantnost projekta/programa

- Proračun (troškovi)

- Prednost u financiranju

Svaka skupina ima podkriterije. Sveukupan broj podkriterija je 17. 
Slika 2. Kriteriji relevantni za odabir programa/projekata u kulturi

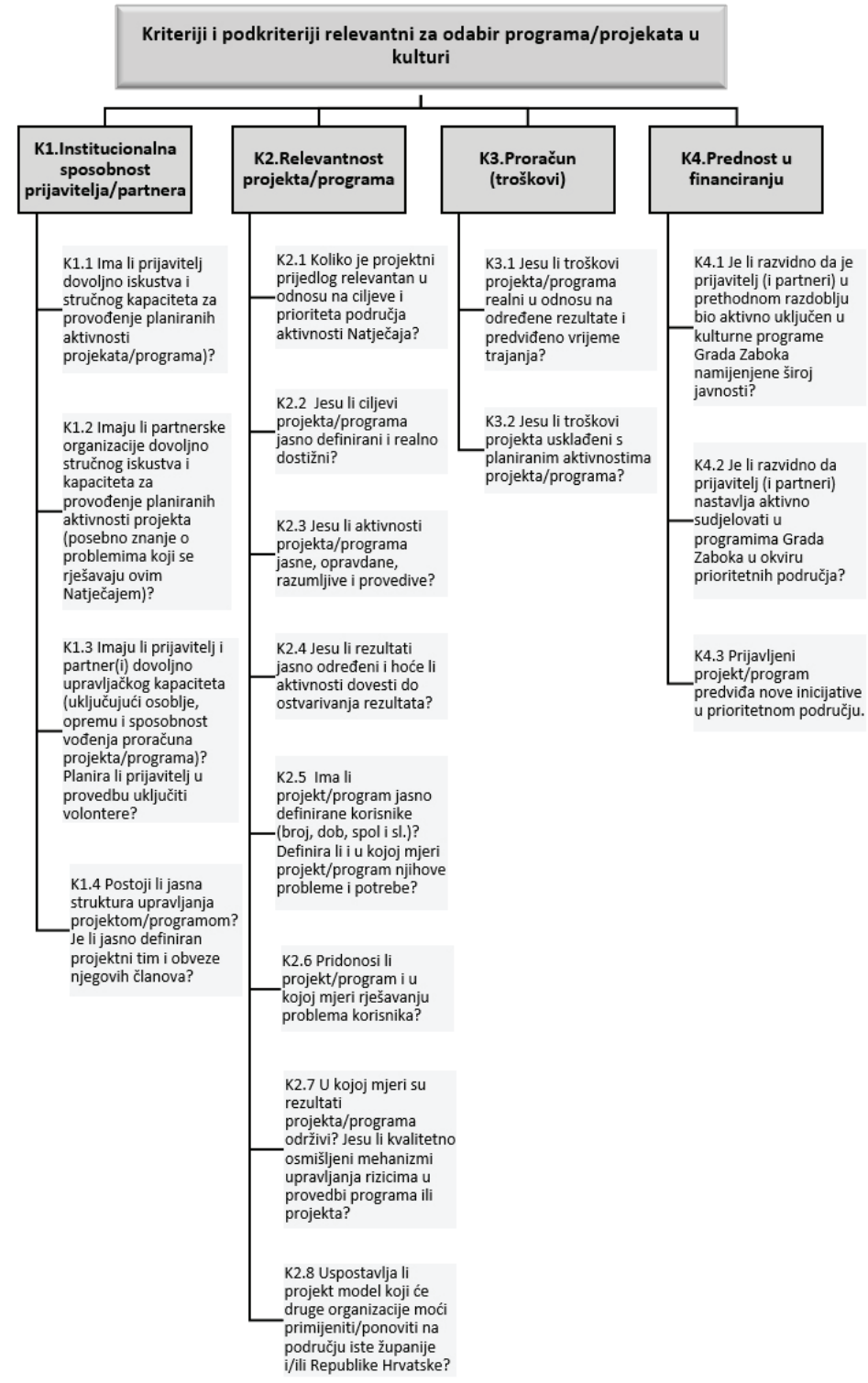

Izvor: obrada autora

\subsection{Procjena važnosti kriterija i podkriterija u parovima}

U drugom koraku razvoja AHP modela izvršena je usporedba kriterija u parovima grupnim odlučivanjem prema Saatyjevoj ljestvici relativne važnosti (Tablica 1.). Prema Hunjak (2004) Saatyjeva ljestvica omogućuje da pojedinac, ako poznaje problematiku na koju se odnosi problem 


\section{V. Đurek, C. Sedda: Primjena metoda odlučivanja u lokalnoj samoupravi Zbornik Veleučilišta u Rijeci, Vol. 8 (2020), No. 1, pp. 203-226}

odlučivanja, može koristiti tu ljestvicu za davanje konzistentnih procjena važnosti kriterija u parovima. Sudionici () u grupnom odlučivanju bili su članovi Odbora za kulturu Grada Zaboka, viša stručna suradnica za društvene djelatnosti i pročelnik Upravnog odjela za komunalno gospodarstvo i javne potrebe te zamjenica gradonačelnika ujedno i predsjednica Odbora za kulturu Grada Zaboka. Drugim riječima, u istraživanje su uključeni sudionici s komplementarnim znanjima o provedbi javnog natječaja. Nakon provedenog grupnog odlučivanja dobiveni su rezultati koji se mogu analizirati i interpretirati zasebno za svakog sudionika i grupno kao sinteza rezultata sudionika procesa grupnog odlučivanja.

\subsubsection{Matrica procijenjenih omjera važnosti kriterija i podkriterija}

U trećem koraku razvoja AHP modela formirana je matrica procijenjenih omjera važnosti kriterija K1, K2, K3 i K 4 (Tablica 2). Proračun je izrađen alatu Microsoft Excel. U redu i stupcu matrice nalazi se vrijednost procijenjenog omjera prioriteta kriterija $i$ kriterija , tj:

$$
\begin{aligned}
& \mathrm{K}_{1}: \mathrm{K}_{3}=3 \\
& \mathrm{~K}_{1}: \mathrm{K}_{4}=2 \\
& \mathrm{~K}_{2}: \mathrm{K}_{1}=2 \\
& \mathrm{~K}_{2}: \mathrm{K}_{3}=3 \\
& \mathrm{~K}_{2}: \mathrm{K}_{4}=4 \\
& \mathrm{~K}_{3}: \mathrm{K}_{4}=3
\end{aligned}
$$

Tablica 2. Matrica relativnih procjena težina - Sudionik 1

\begin{tabular}{|c|c|c|c|c|}
\hline Kriteriji & K1 & K2 & K3 & K4 \\
\hline K1 & 1 & $1 / 2$ & 3 & 2 \\
\hline K2 & 2 & 1 & 3 & 4 \\
\hline K3 & $1 / 3$ & $1 / 3$ & 1 & 3 \\
\hline K4 & $1 / 2$ & $1 / 4$ & $1 / 3$ & 1 \\
\hline \multicolumn{5}{|c|}{ Izvor: obrada autora } \\
\hline
\end{tabular}

Rezultati usporedbe kriterija u parovima za preostalih pet sudionika istraživanja prikazani su u matrici procijenjenih omjera važnosti kriterija K1, K2, K3 i K4 (Tablica 3 - Tablica 7). 
Tablica 3. Matrica relativnih procjena težina - Sudionik 2

\begin{tabular}{|c|c|c|c|c|}
\hline Kriteriji & K1 & K2 & K3 & K4 \\
\hline K1 & 1 & $1 / 3$ & $1 / 2$ & 3 \\
\hline K2 & 3 & 1 & 3 & 3 \\
\hline K3 & 2 & $1 / 3$ & 1 & 3 \\
\hline K4 & $1 / 3$ & $1 / 3$ & $1 / 3$ & 1 \\
\hline
\end{tabular}

Izvor: obrada autora

Tablica 4. Matrica relativnih procjena težina - Sudionik 3

\begin{tabular}{|c|c|c|c|c|}
\hline Kriteriji & K1 & K2 & K3 & K4 \\
\hline K1 & 1 & $1 / 4$ & $1 / 3$ & $1 / 2$ \\
\hline K2 & 4 & 1 & 2 & 3 \\
\hline K3 & 3 & $1 / 2$ & 1 & 3 \\
\hline K4 & 2 & $1 / 3$ & $1 / 3$ & 1 \\
\hline \multicolumn{5}{|c|}{ Izvor: obrada autora } \\
\hline
\end{tabular}

Tablica 5. Matrica relativnih procjena težina - Sudionik 4

\begin{tabular}{|c|c|c|c|c|}
\hline Kriteriji & K1 & K2 & K3 & K4 \\
\hline K1 & 1 & $1 / 3$ & $1 / 3$ & 2 \\
\hline K2 & 3 & 1 & 2 & 4 \\
\hline K3 & 3 & $1 / 2$ & 1 & 3 \\
\hline K4 & $1 / 2$ & $1 / 4$ & $1 / 3$ & 1 \\
\hline \multicolumn{5}{|c|}{ Izvor: obrada autora } \\
\hline
\end{tabular}

Tablica 6. Matrica relativnih procjena težina - Sudionik 5

\begin{tabular}{|c|c|c|c|c|}
\hline Kriteriji & K1 & K2 & K3 & K4 \\
\hline K1 & 1 & $1 / 2$ & $1 / 3$ & 2 \\
\hline K2 & 2 & 1 & 3 & 3 \\
\hline K3 & 3 & $1 / 3$ & 1 & 3 \\
\hline K4 & $1 / 2$ & $1 / 3$ & $1 / 3$ & 1 \\
\hline \multicolumn{5}{|c|}{ Izvor: obrada autora } \\
\hline
\end{tabular}


Tablica 7. Matrica relativnih procjena težina - Sudionik 6

\begin{tabular}{|c|c|c|c|c|}
\hline Kriteriji & K1 & K2 & K3 & K4 \\
\hline K1 & 1 & $1 / 4$ & 2 & 2 \\
\hline K2 & 4 & 1 & 4 & 4 \\
\hline K3 & $1 / 2$ & $1 / 4$ & 1 & 2 \\
\hline K4 & $1 / 2$ & $1 / 4$ & $1 / 2$ & 1 \\
\hline \multicolumn{5}{|c|}{ lzvor: obrada autora } \\
\hline
\end{tabular}

Uz prethodno prikazane rezultate usporedbe kriterija u parovima, svaki sudionik istraživanja uspoređivao je u parovima dodatno četiri grupe podkriterija: podkriterije, podkriterije, podkriterije i podkriterije prema kojima su izrađene matrice procijenjenih omjera važnosti podkriterija. $U$ Tablica 8 - 11 prikazani su rezultati za jednog od sudionika istraživanja - Sudionik 1.

Tablica 8. Matrica relativnih procjena težina podkriterija - Sudionik 1

\begin{tabular}{|c|c|c|c|c|}
\hline Kriteriji & K1.1 & K1.2 & K1.3 & K1.4 \\
\hline K1.1 & 1 & $1 / 2$ & $1 / 3$ & $1 / 3$ \\
\hline K1.2 & 2 & 1 & $1 / 2$ & $1 / 3$ \\
\hline K1.3 & 3 & 2 & 1 & 3 \\
\hline K1.4 & 3 & 3 & $1 / 3$ & 1 \\
\hline \multicolumn{5}{|c|}{ Izvor: obrada autora } \\
\hline
\end{tabular}

Tablica 9. Matrica relativnih procjena težina podkriterija - Sudionik 1

\begin{tabular}{|c|c|c|c|c|c|c|c|c|}
\hline Kriteriji & K2.1 & K2.2 & K2.3 & K2.4 & K2.5 & K2.6 & K2.7 & K2.8 \\
\hline K2.1 & 1 & $1 / 2$ & $1 / 2$ & $1 / 3$ & $1 / 3$ & $1 / 3$ & $1 / 3$ & $1 / 4$ \\
\hline K2.2 & 2 & 1 & 3 & 2 & 2 & $1 / 2$ & $1 / 2$ & $1 / 3$ \\
\hline K2.3 & 2 & $1 / 3$ & 1 & $1 / 3$ & 2 & $1 / 2$ & $1 / 2$ & $1 / 2$ \\
\hline K2.4 & 3 & $1 / 2$ & 3 & 1 & 3 & 2 & 2 & $1 / 2$ \\
\hline K2.5 & 3 & $1 / 2$ & $1 / 2$ & $1 / 3$ & 1 & 3 & $1 / 2$ & $1 / 3$ \\
\hline K2.6 & 3 & 2 & 2 & $1 / 2$ & $1 / 3$ & 1 & 3 & 3 \\
\hline K2.7 & 3 & 2 & 2 & $1 / 2$ & 2 & $1 / 3$ & 1 & 2 \\
\hline K2.8 & 4 & 3 & 2 & 2 & 3 & $1 / 3$ & $1 / 2$ & 1 \\
\hline
\end{tabular}


Tablica 10. Matrica relativnih procjena težina podkriterija - Sudionik 1

\begin{tabular}{|c|c|c|}
\hline Kriteriji & K3.1 & K3.2 \\
\hline K3.1 & 1 & 3 \\
\hline K3.2 & $1 / 3$ & 1 \\
\hline \multicolumn{3}{|c|}{ Izvor: obrada autora } \\
\hline
\end{tabular}

Tablica 11. Matrica relativnih procjena težina podkriterija - Sudionik 1

\begin{tabular}{|c|c|c|c|}
\hline Kriteriji & K4.1 & K4.2 & K4.3 \\
\hline K4.1 & 1 & 2 & $1 / 3$ \\
\hline K4.2 & $1 / 2$ & 1 & $1 / 3$ \\
\hline K4.3 & 3 & 3 & 1 \\
\hline \multicolumn{4}{|c|}{ Izvor: obrada autora } \\
\hline
\end{tabular}

Vrlo važna značajka u primijeni AHP metode je konzistentnost procjena donositelja odluke. Prema Formanu i Selly (2001) AHP metoda spada u primjenjive metode i zato što ima sposobnost identificirati i analizirati nekonzistentnost donositelja odluke u procesu uspoređivanja elemenata hijerarhije. Čovjek je rijetko konzistentan pri procjenjivanju vrijednosti ili odnosa kvalitativnih elemenata u hijerarhiji, a uzroci nekonzistentnosti mogu biti različiti: pomanjkanje koncentracije, administrativna greška, nepostojanje konzistencije u stvarnom problemu koji treba modelirati, neadekvatna struktura modela, nedostatak informacija. Autor Hunjak (2004) navodi da je nekonzistentnost moguće najjednostavnije objasniti pomoću sljedećeg primjera. Pretpostavimo da imamo tri kamena A, B i C za koje znamo da ukupno teže $22 \mathrm{~kg}$, ali nam nisu poznate njihove pojedinačne težine. Mi znamo njihove omjere težina (kamen $A$ je dvostruko teži od kamena $B$ ) i (kamen A je trostruko teži od kamena C). Iz ovoga proizlazi diobeni omjer težina iz kojeg lako izračunamo da su tražene težine kamena redom 12, 6 i 4 kg. Umjesto kamena možemo zamisliti da međusobno uspoređujemo kriterije te im izračunavamo težine kao mjeru njihove važnosti. Isto tako možemo uspoređivati alternative po prioritetima kako bismo odredili prioritet svake od njih. Problemi nastaju zbog toga što naše procjene obično nisu konzistentne.

Tijekom procjene važnosti kriterija u parovima provjerava se konzistentnost procjena donositelja odluke i utvrđuje ispravnost dobivenih težinskih koeficijenata kriterija i prioriteta alternativa. Da bi matematički utvrdili konzistentnost matrice, koristi se sljedeći postupak:

- izračunaju se sume stupaca,

- normira se matrica (svaki stupac se podijeli sa zbrojem elemenata tog stupca),

- u normiranoj matrici se izračunaju sume redova - težine ,

- težine se podijele s vektorom prioriteta prve matrice,

- izračuna se $\lambda \max$ kao prosječna vrijednost dobivenih veličina. 


\section{V. Đurek, C. Sedda: Primjena metoda odlučivanja u lokalnoj samoupravi Zbornik Veleučilišta u Rijeci, Vol. 8 (2020), No. 1, pp. 203-226}

AHP metoda omogućuje praćenje konzistentnosti procjena u svakom trenutku postupka. Autori Saaty i Vargas (2012) definiraju indeks konzistencije kao: $C I=\frac{(\lambda m a x-n)}{(n-1)}$.

Autori Hunjak i Jakovčević (2003) objašnjavaju izračunavanje omjera konzistencije s pomoću navedenog indeksa konzistencije kao $C R=\frac{C I}{R I}$ gdje je RI slučajni indeks (indeks konzistencije za matrice reda $n$ slučajno generiranih usporedaba u parovima, Tablica 12.) računa se $\mathbf{C R}$, omjer konzistencije.

Tablica 12. Vrijednosti RI slučajnih indeksa

\begin{tabular}{|c|c|c|c|c|c|c|c|c|c|c|}
\hline $\mathbf{n}$ & 1 & 2 & 3 & 4 & 5 & 6 & 7 & 8 & 9 & 10 \\
\hline $\mathbf{R I}$ & 0 & 0 & 0,52 & 0,89 & 1,11 & 1,25 & 1,35 & 1,40 & 1,45 & 1,49 \\
\hline
\end{tabular}

Izvor: T. L. Saaty (1980)

Ako za matricu $A$ vrijedi $C R \leq 0,10$, procjene relativnih važnosti kriterija (prioriteta alternativa) smatraju se prihvatljivima.

Indeks konzistencije (CR) kod svih matrica u ovom istraživanju je prihvatljiv i iznosi $\leq 0,10$, tj. manje ili jednako od 10\% (Tablica 13.).

Tablica 13. Rezultati indeksa konzistencije (CR)

\begin{tabular}{|c|c|}
\hline Kriteriji & $\begin{array}{c}\text { Indeks } \\
\text { konzistencije }\end{array}$ \\
\hline $\mathrm{K} 1-\mathrm{K} 4$ & 0,02 \\
\hline $\mathrm{K} 1.1-\mathrm{K} 1.4$ & 0,03 \\
\hline $\mathrm{K} 2.1-\mathrm{K} 2.8$ & $-0,05$ \\
\hline $\mathrm{K} 4.1-\mathrm{K} 4.3$ & 0,02 \\
\hline
\end{tabular}

Izvor: obrada autora

\section{3.4 Izračun težinskih koeficijenata kriterija i podkriterija}

U četvrtom se koraku pristupilo računanju težinskih koeficijenata kriterija i podkriterija (Tablica 14.) tako da su zbrojeni stupci matrice, a na temelju toga izračunala se normalizirana matrica tako da se svaki element prethodne matrice podijelio sa zbrojem stupca kojem pripada. Nakon toga izračunate su težine koeficijenata kriterija i težine koeficijenata podkriterija, tj. prioriteti kao prosječne vrijednosti elemenata redova normalizirane matrice. Zatim se geometrijskom sredinom rezultata dobivenih kod sudionika istraživanja izračunala ukupna težina koeficijenata kriterija i težina koeficijenata podkriterija (Tablica 12.). Istraživanje je pokazalo da najveći težinski koeficijent 0,49 ima kriterij K2.Relevantnost projekta/programa koji obuhvaća podkriterije K2.1 (čija težinska vrijednost iznosi 0,18), K2.4 (čija težinska vrijednost iznosi 0,17), K2.2 (čija težinska vrijednost iznosi 0,14 ), K2.3 (čija težinska vrijednost iznosi 0,13), K2.7 (čija težinska vrijednost iznosi 0,10), K2.6 
(čija težinska vrijednost iznosi 0,10), K2.5 (čija težinska vrijednost iznosi 0,09) i K2.8 (čija težinska vrijednost iznosi 0,08).

Zatim slijedi kriterij K3.Proračun (troškovi) s težinskim koeficijentom 0,24. koji obuhvaća podkriterije K3.1 (čija težinska vrijednost iznosi 0,60) i K3.2 (čija težinska vrijednost iznosi 0,40).

Treći kriterij po važnosti je K1.Institucionalna sposobnost prijavitelja/partnera s težinskim koeficijentom 0,17 koji obuhvaća podkriterije K1.3 (čija težinska vrijednost iznosi 0,31), K1.4 (čija težinska vrijednost iznosi 0,28), K1.1 (čija težinska vrijednost iznosi 0,25) i K1.2 (čija težinska vrijednost iznosi 0,15$)$.

Najmanju važnost ima kriterij K4.Prednost u financiranju s težinskim koeficijentom 0,11 koji obuhvaća podkriterije K4.2 (čija težinska vrijednost iznosi 0,37), K4.1 (čija težinska vrijednost iznosi 0,32 ) i K4.3 (čija težinska vrijednost iznosi 0,30).

Tablica 14. Pregled težinskih koeficijenta kriterija i podkriterija

\begin{tabular}{|l|c|}
\hline \multicolumn{1}{|c|}{ Kriteriji i podkriteriji } & $\begin{array}{c}\text { Težinski } \\
\text { koeficijenti }\end{array}$ \\
\hline K1.Institucionalna sposobnost prijavitelja/partnera & $\mathbf{0 , 1 7}$ \\
\hline $\begin{array}{l}\text { K1.1 Ima li prijavitelj dovoljno iskustva i stručnog kapaciteta za provođenje } \\
\text { planiranih aktivnosti projekata/programa? }\end{array}$ & 0,25 \\
\hline $\begin{array}{l}\text { K1.2 Imaju li partnerske organizacije dovoljno stručnog iskustva i kapaciteta } \\
\text { za provođenje planiranih aktivnosti projekta (posebno znanje o problemima } \\
\text { koji se rješavaju ovim Natječajem)? }\end{array}$ & 0,15 \\
\hline $\begin{array}{l}\text { K1.3 Imaju li prijavitelj i partner(i) dovoljno upravljačkog kapaciteta } \\
\text { (uključujući osoblje, opremu i sposobnost vođenja proračuna projekta/ } \\
\text { programa)? Planira li prijavitelj u provedbu uključiti volontere? }\end{array}$ & 0,31 \\
\hline $\begin{array}{l}\text { K1.4 Postoji li jasna struktura upravljanja projektom/programom? je li jasno } \\
\text { definiran projektni tim i obveze njegovih članova? }\end{array}$ & 0,28 \\
\hline K2.Relevantnost projekta/programa & $\mathbf{0 , 4 9}$ \\
\hline $\begin{array}{l}\text { K2.1 Koliko je projektni prijedlog relevantan u odnosu na ciljeve i prioriteta } \\
\text { područja aktivnosti Natječaja (je li projekt/program u skladu s mjerama i } \\
\text { aktivnostima u planiranim nacionalnim/regionalnim/lokalnim programima, } \\
\text { strategijama i politikama koje su u nadležnosti davatelja financijskih } \\
\text { potpora)?* }\end{array}$ & 0,18 \\
\hline K2.2 Jesu li ciljevi projekta/programa jasno definirani i realno dostižni? & 0,13 \\
\hline $\begin{array}{l}\text { K2.3 Jesu li aktivnosti projekta/programa jasne, opravdane, razumljive i } \\
\text { provedive? }\end{array}$ & 0,14 \\
\hline
\end{tabular}




\begin{tabular}{|l|c|}
\hline $\begin{array}{l}\text { K2.4 Jesu li rezultati jasno određeni i hoće li aktivnosti dovesti do ostvarivanja } \\
\text { rezultata? }\end{array}$ & 0,17 \\
\hline $\begin{array}{l}\text { K2.5 Ima li projekt/program jasno definirane korisnike (broj, dob, spol i sl.)? } \\
\text { Definira li i u kojoj mjeri projekt/program njihove probleme i potrebe? }\end{array}$ & 0,09 \\
\hline $\begin{array}{l}\text { K2.6 Pridonosi li projekt/program i u kojoj mjeri rješavanju problema } \\
\text { korisnika? }\end{array}$ & 0,10 \\
\hline $\begin{array}{l}\text { K2.7 U kojoj mjeri su rezultati projekta/programa održivi? Jesu li kvalitetno } \\
\text { osmišljeni mehanizmi upravljanja rizicima u provedbi programa ili projekta? }\end{array}$ & 0,10 \\
\hline $\begin{array}{l}\text { K2.8 Uspostavlja li projekt model koji će druge organizacije moći primijeniti/ } \\
\text { ponoviti na području iste županije i/ili Republike Hrvatske? }\end{array}$ & 0,08 \\
\hline K3.Proračun (troškovi) & $\mathbf{0 , 2 4}$ \\
\hline $\begin{array}{l}\text { K3.1 Jesu li troškovi projekta/programa realni u odnosu na određene rezultate } \\
\text { i predviđeno vrijeme trajanja? }\end{array}$ & 0,60 \\
\hline $\begin{array}{l}\text { K3.2 Jesu li troškovi projekta usklađeni s planiranim aktivnostima projekta/ } \\
\text { programa? }\end{array}$ & 0,40 \\
\hline K4.Prednost u financiranju & $\mathbf{0 , 1 1}$ \\
\hline $\begin{array}{l}\text { K4.1 Je li razvidno da je prijavitelj (i partneri) u prethodnom razdoblju bio } \\
\text { aktivno uključen u kulturne programe Grada Zaboka namijenjene široj } \\
\text { javnosti? }\end{array}$ & 0,30 \\
\hline $\begin{array}{l}\text { K4.2 Je li razvidno da prijavitelj (i partneri) nastavlja aktivno sudjelovati u } \\
\text { programima Grada Zaboka u okviru prioritetnih područja? }\end{array}$ & 0,37 \\
\hline $\begin{array}{l}\text { K4.3 Prijavljeni projekt/program predviđa nove inicijative u prioritetnom } \\
\text { području. }\end{array}$ & 0,32 \\
\hline
\end{tabular}

Izvor: obrada autora

\subsection{Analiza osjetljivosti}

Analiza osjetljivosti se provodi s ciljem da se vidi u kojoj mjeri moguće promjene vrijednosti ulaznih varijabli modela utječu na izlazne vrijednosti varijabli modela. Na temelju analize osjetljivosti mogu se procijeniti posljedice realizacije odluke u različitim situacijama. Analiza osjetljivosti koristi se i za ispitivanje kvalitete modela odnosno provođenjem iste moguće je vidjeti u kojoj mjeri model omogućuje prepoznavanje manjih promjena u parametrima odluke, koji spadaju pod kontrolom donositelja odluke i promjenama parametara kojima se opisuje stanje okoline odnosno onih koje donositelj odluke ne kontrolira, ali također utječu na posljedice odluke. Prema Munđaru i Hunjaku (2012) analiza osjetljivosti preporučuje se i za donošenje odluka u javnom sektoru, dakle ona se ne provodi samo u poslovnom odlučivanju. 
Analiza osjetljivosti provedena je tako da su se mijenjali težinski koeficijenti pojedinih kriterija za +/- 5\% (uz odgovarajuće promjene u težinama ostalih kriterija kako bi suma težinskih koeficijenta bila 100\%) i promatrale su se promjene u odnosu na težinske koeficijente prikazane u Tablici 14.

Nakon provedene analize osjetljivosti možemo zaključiti da je razvijeni AHP model odlučivanja osjetljiv na smanjenje ili povećanje težine kriterija K1.Institucionalna sposobnost prijavitelja/ partnera, na povećanje težine kriterija K2.Relevantnost projekta/programa i na povećanje kriterija K4.Prednost u financiranju. Nadalje, model odlučivanja malo je osjetljiv na smanjenje težine kriterija K2.Relevantnost projekta/programa i na smanjenje težine kriterija K4.Prednost u financiranju.

Model odlučivanja nije osjetljiv na smanjenje ili povećanje težine kriterija K3.Proračun (troškovi).

Rezultat provedenih osam analiza osjetljivosti pokazuje da ni u jednoj nije promijenjen rang alternativa od rangiranih 14. - 18. mjesta.

\section{VALIDACIJA NA TEMELJU POVIJESNIH PODATAKA}

Nakon provedenog istraživanja i modeliranja izrađena je usporedba dobivenih rezultata rangiranja alternativa dobivenih korištenjem postojećeg modela donošenja odluka i rangiranja alternativa dobivenih korištenjem razvijenog AHP modela pri čemu su se koristili podaci iz 2018. godine.

Postojeći model donošenja odluka rangiranja programa/projekta udruga u kulturi koristi statističku metodu aritmetičke sredine. Aritmetička sredina, kao prosječna vrijednost obilježja svih jedinica skupa, izravnava apsolutne razlike između podataka promatrane serije. Nakon što Povjerenstvo ocijeni svaki pristigli program/projekt na javni natječaj, računa se aritmetička sredina rezultata ocjenjivanja Povjerenstva. Dobiveni rezultati se rangiraju, odnosno određuje se koje će se alternative - programi/projekti udruga u kulturi financirati u tekućoj godini.

Rezultati usporedbe korištenja sadašnjeg modela donošenja odluka i razvijenog AHP modela prikazani su u Tablica 15. iz koje je vidljivo da došlo do promjena. Promjene su vidljive u rangiranju od 12.-15. mjesta.

Možemo zaključiti da korištenjem AHP modela dolazi do promjena u rangiranju u odnosu na postojeći model jer AHP model određuje težinske koeficijente alternativa pa je tako moguća razlika u rangiranju istih posebno kod onih koje su rangirane jedna iza/ispred druge tj. kod kojih je mala razlika u izračunima primjenom sadašnjeg modela izračuna prioriteta.

Rezultat primjene AHP modela za rangiranje programa/projekata udruga u kulturi daje ne samo matematički preciznije rezultate već dovodi do toga da se za financiranje putem javnog natječaja odabiru kvalitetniji programi/projekti udruga što je i cilj provedenog natječaja. 
Tablica 15. Validacija modela na temelju povijesnih podataka

\begin{tabular}{|c|c|c|}
\hline \multicolumn{3}{|c|}{$\begin{array}{c}\text { Rangiranje alternativa } \\
\text { aritmetičkom sredinom }\end{array}$} \\
\hline Rang & Alternative & Prioritet \\
\hline 1 & P16 & 101,00 \\
\hline 2 & P17 & 99,66 \\
\hline 3 & P12 & 99,00 \\
\hline 4 & P18 & 97,66 \\
\hline 5 & P10 & 96,66 \\
\hline 6 & P11 & 96,33 \\
\hline 7 & P14 & 96,33 \\
\hline 8 & P13 & 96,33 \\
\hline 9 & P15 & 94,33 \\
\hline 10 & P2 & 90,66 \\
\hline 11 & P6 & 90,66 \\
\hline 12 & P8 & 89,66 \\
\hline 13 & P7 & 89,33 \\
\hline 14 & P9 & 88,33 \\
\hline 15 & P3 & 87,33 \\
\hline 16 & P5 & 80,66 \\
\hline 17 & P4 & 79,33 \\
\hline 18 & P1 & 55,66 \\
\hline
\end{tabular}

\begin{tabular}{|c|c|c|}
\hline \multicolumn{3}{|c|}{$\begin{array}{c}\text { Rangiranje alternativa korištenjem } \\
\text { metode AHP }\end{array}$} \\
\hline Rang & Alternative & Prioritet \\
\hline 1 & P16 & 6,72 \\
\hline 2 & P17 & 6,71 \\
\hline 3 & P12 & 6,62 \\
\hline 4 & P18 & 6,52 \\
\hline 5 & P10 & 6,52 \\
\hline 6 & P11 & 6,52 \\
\hline 7 & P14 & 6,51 \\
\hline 8 & P13 & 6,48 \\
\hline 9 & P15 & 6,40 \\
\hline 10 & P2 & 5,97 \\
\hline 11 & P6 & 5,96 \\
\hline 12 & P7 & 5,83 \\
\hline 13 & P8 & 5,82 \\
\hline 14 & P3 & 5,62 \\
\hline 15 & P9 & 5,45 \\
\hline 16 & P5 & 5,10 \\
\hline 17 & P4 & 4,99 \\
\hline 18 & P1 & 3,73 \\
\hline
\end{tabular}

Izvor: obrada autora

\section{ANALIZA RIZIKA}

Na najopćenitijoj razini, rizik može značiti opasnost, gubitak ili neizvjesnost u pogledu posljedica budućeg događaja. U statistici, financijskom i investicijskom menadžmentu to pak znači varijabilnost ishoda odnosno odstupanje od određene očekivane vrijednosti.

Postoje različite definicije rizika, a najčešće se pod tim pojmom podrazumijeva opasnost da neki pothvat ne uspije ili se smanji očekivani rezultat, odnosno mogućnost nepovoljnog odstupanja od srednjeg očekivanja. Slični smisao imaju i definicije rizika kao stupnja podložnosti negativnim događajima i njihovim vjerojatnim posljedicama ili kao izloženost nezgodi, nesreći propasti, gubitku. Šire značenje definira rizik kao neizvjestan događaj ili stanje koje, ako se pojavi, ima pozitivan ili negativan utjecaj na ciljeve projekta (PMBOK Guide, 2000).

Autor Willet (1951) definira rizik kao objektiviziranu neizvjesnost ostvarenja neželjenog događaja. Rizik predstavlja kombinaciju vjerojatnosti događaja i negativnih posljedica gdje se u što većoj 
mjeri utječe na smanjenje jednog i drugog. Potrebno je razlikovati rizik, uzrok i posljedicu. Za svaki rizik postoji uzrok, a posljedica će postojati ako se rizik ostvari. Uzrok je postojeća situacija koja potiče rizik, a posljedica je rezultat nastanka rizika.

Rizik se uglavnom promatra kao negativan utjecaj na ukupnu situaciju, ali se isti može promatrati i kao prilika zato što ponekad rizik daje i neke pozitivne mogućnosti i može poboljšati ostvarenje projektnih ciljeva. Kod rizika je bitno razumjeti da se na neke može utjecati, da se mogu kontrolirati i smanjiti, ali se nikada ne mogu u potpunosti eliminirati. Osim toga, vrlo je važno razgraničiti pojmove vjerojatnosti i neizvjesnosti od rizika jer oni nisu istoznačni iako se nekad pogrešno poistovjećuju u svakodnevnom govoru.

Rizik i neizvjesnost karakteriziraju situacije gdje stvarni rezultat za pojedini događaj ili aktivnost ima više od jedne moguće vrijednosti. Uvriježeno je mišljenje da je rizik podložan statističkoj procjeni i proračunu, a neizvjesnost (= neznanje) nije. Kod neizvjesnosti se radi o subjektivnoj vjerojatnosti, ona nema mjerne atribute i ne može se ukalkulirati u planove. Kod rizika je poznato stanje u kojem se kao posljedica neke odluke može pojaviti niz rezultata, pri čemu je poznata i vjerojatnost nastupanja svakog pojedinog rezultata.

Prema Kerzneru (2003) rizik se često mjeri kroz:

- vjerojatnost da će se pojaviti,

- učinak na projektne ciljeve ako se pojavi (izloženost projekta tj. stupanj osjetljivosti koji je proporcionalan mogućoj šteti), te se iskazuje se kao umnožak ta dva faktora.

Svi rizici nisu jednako opasni za ustanovu, a to ovisi o njihovim posljedicama:

- Visoko rizičan - posljedice rizika imaju veliki utjecaj na realizaciju i rezultate projekta

- Umjereno rizičan - posljedice rizika imaju umjeren utjecaj na projekt

- Nisko rizičan - posljedice rizika imaju niski utjecaj na projekt.

Klasifikacija rizika u gore navedene kategorije može se izraditi s obzirom na spomenute varijable rizika: posljedice rizika (utjecaj na realizaciju projekta) i vjerojatnost nastanka rizika (Tablica 16).

Tablica 16. Klasifikacija rizika

\begin{tabular}{|c|c|c|c|c|}
\cline { 3 - 5 } \multicolumn{2}{c|}{} & \multicolumn{3}{c|}{ Utjecaj posljedica rizika na realizaciju nastavka suradnje na projektu } \\
\cline { 3 - 5 } \multicolumn{2}{c|}{} & 1 & 2 & 3 \\
\hline $\begin{array}{c}\text { Vjerojatnost } \\
\text { nastanka } \\
\text { rizika }\end{array}$ & 1 & Nisko rizičan & Nisko rizičan & Umjereno rizičan \\
\cline { 2 - 5 } & 2 & Nisko rizičan & Umjereno rizičan & Visoko rizičan \\
\cline { 2 - 5 } & 3 & Umjereno rizičan & Visoko rizičan & Visoko rizičan \\
\hline
\end{tabular}

Izvor: obrada autora 


\section{V. Đurek, C. Sedda: Primjena metoda odlučivanja u lokalnoj samoupravi Zbornik Veleučilišta u Rijeci, Vol. 8 (2020), No. 1, pp. 203-226}

U Tablici 17. identificirani su rizici vezani uz prijavu projekata na Javni natječaj za financiranje programa ili projekata udruga. Osim rizika dana je procjena vjerojatnosti nastanka istih te aktivnosti upravljanja rizicima.

Važno je naglasiti da se rizici opisani u Tablici 17. odnose na Grad Zabok budući da isti kao davatelj financijskih sredstava ima interes financirati najkvalitetnije programe/projekte udruga kojima će ostvariti ciljeve zadane procjenom prioritetnih potreba.

Tablica 17. Identificirani rizici Javnog natječaja za financiranje programa ili projekata udruga

\begin{tabular}{|c|c|c|}
\hline Rizik & $\begin{array}{c}\text { Klasifikacija } \\
\text { rizika }\end{array}$ & Aktivnosti upravljanja rizikom \\
\hline \multirow{3}{*}{$\begin{array}{l}\text { Nestručnost članova } \\
\text { Povjerenstva }\end{array}$} & Nisko rizičan & Nije potrebno poduzimati nikakve akcije. \\
\hline & Umjereno rizičan & $\begin{array}{l}\text { Prije provedbe natječaja provodi se edukacija } \\
\text { članova Povjerenstava. }\end{array}$ \\
\hline & Visoko rizičan & $\begin{array}{l}\text { Članove Povjerenstva moguće je odabrati putem } \\
\text { javnog poziva za prijavu stručnjaka koji žele } \\
\text { sudjelovati u postupku ocjenjivanja prijava. }\end{array}$ \\
\hline \multirow{3}{*}{$\begin{array}{c}\text { Subjektivnost } \\
\text { članova Povjerenstva }\end{array}$} & Nisko rizičan & Nije potrebno poduzimati nikakve akcije. \\
\hline & Umjereno rizičan & $\begin{array}{c}\text { Nakon otvaranja pristiglih prijava, članovi } \\
\text { Povjerenstva obavezno potpisuju Izjavu o } \\
\text { nepostojanju sukoba interesa. }\end{array}$ \\
\hline & Visoko rizičan & $\begin{array}{l}\text { Ukoliko se utvrdi da je pojedini član u sukobu } \\
\text { interesa, aktivira se zamjena člana Povjerenstva. }\end{array}$ \\
\hline \multirow{3}{*}{$\begin{array}{l}\text { Utjecaj prijavitelja na } \\
\text { članove Povjerenstva }\end{array}$} & Nisko rizičan & $\begin{array}{l}\text { Imena članova Povjerenstva su tajna do objave } \\
\text { rezultata natječaja. }\end{array}$ \\
\hline & Umjereno rizičan & $\begin{array}{l}\text { Imena članova Povjerenstva mogu se javno } \\
\text { objaviti tek nakon objave rezultata natječaja. }\end{array}$ \\
\hline & Visoko rizičan & $\begin{array}{c}\text { Zbog pokušaja utjecaja na članove Povjerenstva } \\
\text { predmetna prijava se odbacuje. }\end{array}$ \\
\hline \multirow{3}{*}{$\begin{array}{l}\text { Prekratki rokovi } \\
\text { indikativnog } \\
\text { kalendara } \\
\text { natječajnog } \\
\text { postupka }\end{array}$} & Nisko rizičan & Nije potrebno poduzimati nikakve akcije. \\
\hline & Umjereno rizičan & $\begin{array}{l}\text { Rokove je u tijeku natječaja moguće po potrebi } \\
\text { produžiti ali navedena informacija mora biti } \\
\text { dostupna javnosti. }\end{array}$ \\
\hline & Visoko rizičan & $\begin{array}{l}\text { Pogrešno primjena i računanje rokova koji mogu } \\
\text { biti osnova za prigovor na Odluku o financiranju. }\end{array}$ \\
\hline
\end{tabular}




\begin{tabular}{|c|c|c|}
\hline \multirow{3}{*}{$\begin{array}{l}\text { Izrada analize } \\
\text { potreba i definiranje } \\
\text { područja financiranja }\end{array}$} & Nisko rizičan & Nije potrebno poduzimati nikakve akcije. \\
\hline & Umjereno rizičan & $\begin{array}{l}\text { Nepotpuno utvrđivanje razvojnih ciljeva i } \\
\text { prioritetnih područja financijske potpore } \\
\text { organizacijama civilnog društva. }\end{array}$ \\
\hline & Visoko rizičan & $\begin{array}{l}\text { Korištenje netočnih podataka za utvrđivanje } \\
\text { prioritetnih područja financijske potpore } \\
\text { organizacijama civilnog društva što može } \\
\text { rezultirati nepoklapanjem sadržaja i cilja Javnog } \\
\text { natječaja s prioritetnim područjima koje se žele } \\
\text { zadovoljiti. }\end{array}$ \\
\hline \multirow{3}{*}{$\begin{array}{l}\text { Nejasnoće u tekstu } \\
\text { natječaja i obrascima }\end{array}$} & Nisko rizičan & Nije potrebno poduzimati nikakve akcije. \\
\hline & Umjereno rizičan & $\begin{array}{l}\text { Prijavitelji imaju pravo u određenom roku } \\
\text { elektroničkim putem postavljati pitanja davatelju } \\
\text { financijskih sredstava čiji se odgovori na pitanja } \\
\text { moraju javno objaviti kako bi najčešća pitanja } \\
\text { i odgovori bili dostupni svim zainteresiranim } \\
\text { stranama prije proteka roka prijava na natječaj. }\end{array}$ \\
\hline & Visoko rizičan & Potrebno je izvršiti ispravak natječaja. \\
\hline \multirow{3}{*}{$\begin{array}{l}\text { Neobaviještenost } \\
\text { prijavitelja o objavi } \\
\text { javnog natječaja }\end{array}$} & Nisko rizičan & Nije potrebno poduzimati nikakve akcije. \\
\hline & Umjereno rizičan & $\begin{array}{c}\text { Prije objave natječaja mogu se organizirati } \\
\text { radionice za potencijalne prijavitelje te se natječaj } \\
\text { objavljuje na mrežnim stranicama davatelja } \\
\text { sredstava, stranica Ureda vlade RH za udruge } \\
\text { zajedno s obavijesti o natječaju u jednim dnevnim } \\
\text { novinama. }\end{array}$ \\
\hline & Visoko rizičan & $\begin{array}{l}\text { Kako bi svi prijavitelji bili informirani o planiranim } \\
\text { financiranjima davatelja sredstava u tijeku godine, } \\
\text { potrebno je objaviti Godišnji plan natječaja koji } \\
\text { se također objavljuje na mrežnim stranicama } \\
\text { davatelja sredstava i stranicama Ureda vlade RH za } \\
\text { udruge. }\end{array}$ \\
\hline \multirow{3}{*}{$\begin{array}{l}\text { Partnerski odnosi na } \\
\text { projektu }\end{array}$} & Nisko rizičan & Nije potrebno poduzimati nikakve akcije. \\
\hline & Umjereno rizičan & $\begin{array}{l}\text { Potpisivanje izjave o partnerstvu kojima partneri } \\
\text { potvrđuju da se obvezuju pridržavati načela dobre } \\
\text { prakse u partnerstvu i obveza partnera navedenih } \\
\text { u prijavi. }\end{array}$ \\
\hline & Visoko rizičan & $\begin{array}{l}\text { Sklapanje sporazuma o partnerstvu kojim se na } \\
\text { detaljan način uređuju partnerski odnosi. }\end{array}$ \\
\hline
\end{tabular}




\begin{tabular}{|c|c|c|}
\hline \multirow{3}{*}{$\begin{array}{l}\text { Zaštita prava i } \\
\text { interesa djece }\end{array}$} & Nisko rizičan & Nije potrebno poduzimati nikakve akcije. \\
\hline & Umjereno rizičan & $\begin{array}{l}\text { Ovisno o vrsti javnog natječaja u svrhu prijave, } \\
\text { osoba koja će u provedbi projekta biti u kontaktu } \\
\text { s djecom kao korisnicima potpisuje izjavu o } \\
\text { suglasnosti za uvid u kaznenu evidenciju. }\end{array}$ \\
\hline & Visoko rizičan & $\begin{array}{l}\text { Ukoliko se utvrdi da je osoba kojoj su u } \\
\text { prijavljenom projektu povjereni određeni poslovi i } \\
\text { zadaci pravomoćno osuđena za određena kaznena } \\
\text { djela na štetu djece, s prijaviteljem se ne sklapa } \\
\text { ugovor o sufinanciranju. }\end{array}$ \\
\hline \multirow{3}{*}{$\begin{array}{l}\text { Postojanje } \\
\text { dvostrukog } \\
\text { financiranja }\end{array}$} & Nisko rizičan & Nije potrebno poduzimati nikakve akcije. \\
\hline & Umjereno rizičan & $\begin{array}{l}\text { Potpisivanje izjave o nepostojanju dvostrukog } \\
\text { financiranja kojom prijavitelj potvrđuje da za } \\
\text { prijavljeni program ili projekt nije dobio financijska } \\
\text { sredstva na natječajima iz javnih izvora. }\end{array}$ \\
\hline & Visoko rizičan & $\begin{array}{l}\text { Ukoliko se potvrdi neistinitost takve izjave } \\
\text { potpisnik te izjave podliježe kaznenoj i } \\
\text { materijalnoj odgovornosti. }\end{array}$ \\
\hline \multirow{3}{*}{$\begin{array}{l}\text { Nedostavljanje } \\
\text { opisnog i financijskog } \\
\text { izvještaja projekata }\end{array}$} & Nisko rizičan & Nije potrebno poduzimati nikakve akcije. \\
\hline & Umjereno rizičan & $\begin{array}{c}\text { Elektroničkom poštom podsjetiti korisnike s } \\
\text { kojima je sklopljen ugovor o financiranju na } \\
\text { obvezu dostavljanja opisnog i financijskog } \\
\text { izvještaja projekta. }\end{array}$ \\
\hline & Visoko rizičan & $\begin{array}{l}\text { Kao prilog podsjetniku za dostavu izvješća } \\
\text { napominje se kako u slučaju nedostavljanja } \\
\text { izvješća ili njegovog neprihvaćanja od strane } \\
\text { davatelja financijskih sredstava isti ne mogu } \\
\text { podnijeti prijavu na natječaj sljedeće dvije godine. }\end{array}$ \\
\hline \multirow{3}{*}{$\begin{array}{l}\text { Nepotpuna i nejasna } \\
\text { dokumentacija } \\
\text { prijava }\end{array}$} & Nisko rizičan & Nije potrebno poduzimati nikakve akcije. \\
\hline & Umjereno rizičan & $\begin{array}{l}\text { Povjerenstvo može tražiti dodatna pojašnjenja od } \\
\text { prijavitelja ukoliko uočeni nedostaci ne utječu na } \\
\text { sam sadržaj prijave. }\end{array}$ \\
\hline & Visoko rizičan & $\begin{array}{l}\text { Ukoliko se nedostaci ne mogu ispraviti ili se } \\
\text { prijavitelj ne očituje u zadanom roku, prijava se } \\
\text { odbacuje. }\end{array}$ \\
\hline
\end{tabular}

Izvor: obrada autora 


\section{ZAKLJUČAK}

Planiranje i donošenje optimalnih poslovnih odluka zahtjevan je i nimalo lak posao u kojem se pokušavaju predvidjeti potrebe korisnika Proračuna i procijeniti sposobnosti udruga za provođenje planiranih programa/projekata kojima će se realizirati prioritetne potrebe. Proračunom se definiraju kratkoročni ciljevi kojima se realiziraju i strateški ciljevi. Zato je važno da se odluke o aktivnostima koje će se staviti u Proračun donose na transparentan, konzistentan i jasan način.

Cilj ovog istraživanja bio je da se pomoću metode za višekriterijsko odlučivanje Analitički hijerarhijski proces - AHP i definiranih kriterija i podkriterija izradi model za rangiranje prijedloga programa/projekata pristiglih na Javni natječaj za financiranje programa ili projekata udruga Grada Zaboka iz prioritetnog područja kulture. Grupnim odlučivanjem dobile su se vrijednosti težina koeficijenata kriterija i vrijednosti težina koeficijenata podkriterija koji su važni za donošenje odluke o odabiru programa/projekata pristiglih na Javni natječaj. Nakon određivanja vrijednosti težina koeficijenata izradila se validacija na temelju povijesnih podataka iz 2018. godine. Usporedili su se rezultati Javnog natječaja iz 2018. godine koji su dobiveni izračunavanjem aritmetičke sredine s podacima koji su dobiveni primjenom AHP modela na podatke rezultata istog Javnog natječaja iz 2018. Korištenjem AHP modela dolazi do promjena u rangiranju u odnosu na postojeći model iz razloga jer AHP model (Kaluža, 2019) određuje težinske koeficijente kriterija i podkriterija tako da je moguća razlika u rangiranju alternativa posebno kod onih koje su rangirane neposredno jedna iza/ispred druge tj. kod kojih je mala razlika u izračunima primjenom sadašnjeg modela izračuna prioriteta. AHP model se u konačnici pokazao uspješnijim za primjenu na konkretnom predmetu iz razloga jer preciznije ocjenjuje i rangira alternative (projekte) s obzirom na težinske koeficijente kriterija na koje je osjetljiviji pa time dovodi do točnijih rezultata u vidu detektiranja kvalitetnijih programa/projekta udruga u kulturi koji će svojom provedbom znatnije doprinijeti općem dobru što je svakako glavni cilj Javnog natječaja. Bitno je naglasiti kako upravo distinkcija kriterija i podkriterija koji su sami po sebi sličnih ali ne i identičnih prioriteta omogućava ispunjavanje svrhe Javnog natječaja u punom smislu, omogućavajući jasne i precizne rezultate ocjenjivanja prijava na Javni natječaj.

Provedeno istraživanje može se smatrati indikativnim jer se provelo u jednoj jedinici lokalne samouprave korištenjem metode AHP. Pošto se na razini JLS-ova donose strateške odluke među kojima postoji zavisnost između kriterija buduća istraživanja mogu se usmjeriti prema primjeni metoda za višekriterijsko odlučivanje koje modeliraju zavisnosti među kriterijima: metoda ANP (engl. Analytic Network Process) (Kadoić et al., 2017b), (Kadoić, 2018) i metoda SNAP (engl. Social Network Analysis Process) (Kadoić et al., 2017a), (Kadoić et al, 2019).

\section{LITERATURA}

Begičević N. (2008) Višekriterijski modeli odlučivanja u strateškom planiranju uvođenja e-učenja, doktorska disertacija, Sveučilište u Zagrebu, Fakultet organizacije i informatike Varaždin.

Daft, R. L. (2001) Organization Theory and Design, 7th ed. Cincinnati, Ohio: South-Western College Publishing. 


\section{V. Đurek, C. Sedda: Primjena metoda odlučivanja u lokalnoj samoupravi \\ Zbornik Veleučilišta u Rijeci, Vol. 8 (2020), No. 1, pp. $203-226$}

Forman E., Selly M. A. (2001) Decision By Objectives (How to convince others that you are right), World Scientific Publishing Co Pte Ltd.

Harker P. T., Vargas L. G. (1987) The Theory of Ratio Scale Estimation: Saaty's Analytic Hierarchy Process, Manage. Sci., vol. 33, no. 11, pp. 1383-1403.

Hunjak T., Jakovčević, D. (2003) Višekriterijski modeli za rangiranje i uspoređivanje banaka, Zbornik. Ekonomskog. Fakulteta, Zagreb., vol. 1, no. 1, pp. 43-60.

Hunjak T. (2004) Višekriterijsko odlučivanje, Informacijska tehnologija u poslovanju, V. Čerić and M. Varga, Eds. Zagreb:Element, pp. 105-119.

Kadoic N. i Kedmenec I. (2016) Using ICT tools for decision making support in local government units, in Proceedings of 39th International Convention, MIPRO 2016, pp. 1533-1538.

Kadoić N. (2016) ICT technologies and structured dialogue: experience of 'Go, go, NGO!' project, in Proceedings of 39th International Convention, MIPRO 2016, pp. 1792-1797.

Kadoić N. (2017) Citizen Participation in Decision Making Processes in Croatian Local Government Units, Int. J. Sci. Eng. Investig., vol. 6, no. 60, pp. 14-22.

Kadoić, N., Begičević Ređep, N. i Divjak, B. (2017a) A new method for strategic decision-making in higher education, Central European Journal of Operations Research, 26(3), pp. 611-628.

Kadoić, N., Begičević Ređep, N., Divjak, B. (2017b) Decision Making with the Analytic Network Process, 17th Proceedings. ection for Operational Research (SOR 2017), pp. 180-186.

Kadoić, N. (2018) Characteristics of the Analytic Network Process, a Multi-Criteria Decision-Making Method, Croatian Operational Research Review, 9(2), pp. 235-244.

Kadoić, N., Divjak, B. and Begičević Ređep, N. (2019) Integrating the DEMATEL with the analytic network process for effective decision-making, Central European Journal of Operations Research, 27(3), pp. 653-678.

Kaluža, M., Kalanj, M. i Vukelić, B. (2019) Comparison of Back-End Frameworks for Web Application, Zbornik Veleučilišta u Rijeci, Vol. 7, No. 1, pp. 317-332.

Kerzner, H. (2003) Project Management: A Systems Approach to Planning, Scheduling, and Controlling, 8th Edition, Eight. Berea, Ohio: John Wiley \& Sons, Inc.

Listyaningsih, V., Utami, E. (2018) Decision Support System Performance-Based Evaluation of Village Government using AHP and TOPSIS Methods: Secang Sub-district of Magelang Regency as a Case Study, Intell. Syst. Appl., vol. 4, pp. 18-28.

Magbagbeola, J. A. O., Adetoso, J. A., Magbagbeola, E. O. (2012) Use of multicriteria decision-making (MDM) process to solving agricultural inputs problem in Oriade Local Government Area, Osun State, Nigeria, J. Emerg. Trends Econ. Manag. Sci., vol. 3, no. 1, pp. 99-102.

Munđar, D., Hunjak, T. (2012) Kvalitativni menadžment: Odlučivanje i rangiranje, Sveučilište u Zagrebu, Fakultet organizacije i informatike Varaždin.

Narodne novine, (2015) Uredba o kriterijima, mjerilima i postupcima financiranja i ugovaranja programa i projekata od interesa za opće dobro koje provode udruge, NN 26/2015.

Project Management Institute (2000) A Guide to the Project Management Body of Knowledge (PMBOK ${ }^{\bullet}$ Guide), Newtoown Square; Pennsylvania, USA.

Saaty, T. L. (1972) An eigen value allocation model for prioritization and planning, Philadelphia, USA.

Saaty, T. L. (1977) A scaling method for priorities in hierarchical structures, J. Math. Psychol., vol. 15, no. 3, pp. 234-281.

Saaty, T. L. (1980) The Analytic Hierarchy Process: Planning, Priority Setting, Resource Allocation (Decision Making Series), New York, USA: McGraw-Hill, New York.

Saaty, T. L. (2008) Decision making with the analytic hierarchy process, Int. J. Serv. Sci., vol. 1, no. 1, pp. 83-98. 
Saaty, T. L., Vargas, L. G. (2012) Models, Methods, Concepts \&amp; Applications of the Analytic Hierarchy Process, vol. 175. Boston, MA: Springer US.

Setiawan, H., Wardoyo, R., Istiyanto, J., Santoso, P. (2016) The Group Decision Support System to Evaluate the ICT Project Performance Using the Hybrid Method of AHP, TOPSIS and Copeland Score, Int. J. Adv. Comput. Sci. Appl. , vol. 7, no. 4, pp. 334-341.

Sikavica, P., Bebek, B., Skoko, H., Tipurić, D. (1999) Poslovno odlučivanje, Zagreb: Informator.

Službeni glasnik Krapinsko-zagorske županije, (2015) Pravilnik o financiranju i odobravanju nefinancijskih podrška udrugama, Krapina, 31/2015, p. 2817.

Tot, B., Srđević B., Vujić, B., Russo, M. A. T., Vujić, G. (2016) Evaluation of key driver categories influencing sustainable waste management development with the analytic hierarchy process (AHP): Serbia example, Waste Manag. Res., vol. 34, no. 8, pp. 740-747.

Weihrich, H., Koontz, H. (1998) Menadžment, Zagreb: Mate.

Wiliet, A. H. (1951) The Economic Theory of Risk and Insurance, University of Pennsylvania, Philadelphia, USA. 


\title{
APPLICATION OF DECISION MAKING METHODS IN LOCAL SELF-GOVERNMENT
}

\author{
Valentina Đurek \\ Mag. Inf. Univ. Ec. S, Grad Zabok, Zivtov trg 10, 49210 Zabok, Croatia; e-mail: valentina@zabok.hr

\section{Claudia Sedda} \\ LL. M., Eurobridge, Via Roma 250, Gavoi 08020, Italy; e-mail: info@eubridge.eu
}

\begin{abstract}
Collaboration with associations has been shown through various financial and non-financial support provided by local governments to programs and projects of general interest. This kind of cross-sectoral cooperation has great potential for generating many positive changes and creating the necessary synergies for sustainable social and economic development. To what extent this potential can be achieved largely depends on the quality of criteria, standards and procedures for granting financial and non-financial support as well as the organizational and human resources of public institutions that must successfully monitor and evaluate contracted support products. The main purpose of this paper was to determine whether it is possible to improve the quality of decision making in local government by using decision making methods in decision-making process regarding the financing of cultural associations. For example, the importance (weighting coefficients) of criteria and subcriteria for quality assessment of projects / applications of cultural associations $(N=18)$ will be determined from the area of Zabok. Likewise, in this paper, the AHP method will be used to create a model of program / project rating in cultural association that is financed from the budget of the City of Zabok. The model will be validated on historical data from 2018.
\end{abstract}

Key words: multi-criteria decision making, AHP, risk matrix, associations, culture 